\title{
PREFERENCJE AKSJOLOGICZNE NAUCZYCIELI A POSTRZEGANIE WARTOŚCI PRZEZ UCZNIÓW
}

\begin{abstract}
Streszczenie: Artykuł przedstawia wyniki przeprowadzonego przez autora badania na temat rozumienia wartości przez uczniów i ich nauczycieli. Zadaniem respondentów było określenie za pomocą skali obejmującej kontinuum między opcją pragmatyczno-egocentryczną a opcją aksjologiczno-obiektywistyczną sensu takich pojęć, jak: „prawda”, „mądrość”, „sprawiedliwość” i „altruizm”. Ponadto starano się empirycznie sprawdzić, jaki wpływ wywarli, zdaniem uczniów, nauczyciele na ich rozumienie wartości. Na podstawie badania można skonstatować istotne przesunięcie pojmowania wartości przez uczniów w kierunku pragmatyczno-egocentrycznym w stosunku do odpowiedzi udzielonych przez nauczycieli. Odnośnie do drugiej kwestii, zdaniem młodzieży, nauczyciele mają minimalny wpływ na wartości, jakimi kierują się uczniowie.
\end{abstract}

Słowa kluczowe: wartości, wychowanie, prawda, mądrość, sprawiedliwość, altruizm.

\section{Przekaz wartości a oddziaływanie wychowawcze nauczycieli}

Z oddziaływaniem wychowawczym jest jak z językiem polskim w polskiej szkole: każdy nauczyciel ma być wzorem poprawnego posługiwania się językiem ojczystym. Przy całej niedoskonałości powyższej analogii - jako że dużo więcej uwarunkowań dotyczy nabywania przez młodzież usprawnień intelektu i woli niż leksykalno-fonetyczno-stylistycznego kształtu mowy, racjonalnym wydaje się uznanie, że każdy nauczyciel wywiera konkretny wpływ na uczniów, z którymi ma kontakt w szkole. Podobnie zresztą jak wszystkie inne osoby, z którymi młodzi ludzie się spotykają, choć chciałoby się mieć nadzieję, że oddziaływanie nauczycieli jest silniejsze i nieprzypadkowe, zwłaszcza ze względu na jego kierunek i charakter. Oddziaływanie wychowawcze na uczniów jest zarówno tradycyjną powinnością moralną, jak i zobowiązaniem formalnym nauczycieli - przynajmniej w polskim systemie oświaty (Ustawa z dnia 7 września 1991 roku o systemie oświaty). W refleksji autobiograficznej 
wielu osób pojawia się przekonanie, że wpływ, jaki wywarli na nich nauczyciele, był istotnym czynnikiem współkształtującym wrażliwość na wartości.

Aby dookreślić wychowanie, nazywane przez Jacka Woronieckiego trudną, ale ciekawą pracą nad uprawą charakterów (Woroniecki 1961), posłużmy się określeniem autorstwa Wiesławy Wołoszyn-Spirki postulującej nieodrywanie go od wykształcenia - wszak obie strony oddziaływania nauczycielskiego skutkować powinny wewnętrzną przemianą człowieka: wychowanie jest „utrwalaniem więzi człowieka z prawdą [...], jest powodowaniem i utrwalaniem więzi osobowych [...], wykształcenie jest usprawnieniem intelektu człowieka [...] oraz usprawnieniem woli w tym, by dzięki rozumieniu, przekazanemu przez intelekt, wola skierowała nas do tego, co istnieje, także do prawdy i dobra" (Wołoszyn-Spirka 2014, s. 149-150). Autorka ta forsuje tezę, iż nauczyciel powinien być osobą, która za pomocą przekazywania wyznaczonych programem nauczania informacji kształci i wychowuje, wspomaga ucznia „w nabywaniu [...] usprawnień intelektu tak, by potrafił [...] podejmować słuszne decyzje i właściwe wybory. [...] Rolą nauczyciela jest aktywizowanie w uczniu procesu harmonizowania jego działań poznawczych z działaniami woli” (Wołoszyn-Spirka 2014, s. 151). Kontynuując tę myśl, autorka twierdzi ponadto, że edukacji nie sposób oddzielić od formowania charakteru, a „wszystkie nasze czyny są ustawicznym usprawnianiem nas i tych, których wychowujemy" (Wołoszyn-Spirka 2014, s. 151).

Według Edwarda Derenia, od nauczyciela, poza kwalifikacjami zawodowymi, wymaga się „odpowiednich postaw i zachowań moralnych” (Dereń, brw.). Stawia on tezę, iż w pracy nauczyciela „wiele zależy [...] od jego zalet, sprawności, uzdolnień, kwalifikacji moralnej", a decydującą rolę odgrywa w niej aspekt osobowy jego relacji z uczniem (Dereń, brw.). Do podstawowych zadań realizowanych w rzeczywistości szkolno-wychowawczej zaliczają się jego zdaniem: wspólne poszukiwanie przez nauczyciela i uczniów prawdy, otwarcie na otaczającą rzeczywistość i życie społeczne, przez uczestniczenie w niej i dążenie do współkreowania postaw moralnych, których przedmiotem są obiektywne wartości etyczne (Dereń, brw.). Właśnie kształtowaniu postaw moralnych (zarówno nauczyciela wychowawcy, jak i ucznia-wychowanka), dokonującemu się za sprawą odkrywania wartości etycznych w autentycznym kontakcie interpersonalnym - cytowany autor przypisuje szczególną rolę.

Podobnie jak przywołani powyżej autorzy, Kazimierz Szewczyk twierdzi, że główną powinnością nauczycielską jest wychowanie człowieka mądrego. Jego zdaniem oznacza to ukształtowanie ,jednostki dysponującej wiedzą etyczną i umiejętnościami pozwalającymi jej oceniać w świetle owej wiedzy konkretne sytuacje wyboru i podejmować decyzje, za które bierze i ponosi całkowitą odpowiedzialność moralną" (Szewczyk 1998, s. 9-10). W tym kontekście przywoływane bywa wywodzące się sprzed paru pokoleń porównanie sytuacji szewca i nauczyciela: o ile na jakość efektów pracy szewca nie ma wpływu moralny - i szerzej: aksjologiczny aspekt jego życia, o tyle nie może być dobrym nauczycielem np. osoba niebędąca człowiekiem mądrym zarówno w życiu prywatnym, jak i społecznym. Z myślą 
tą koresponduje kategoria kompetencji praktyczno-moralnych nauczyciela (i ich prymatu nad technicznymi) w ujęciu Roberta Kwaśnicy (Kwaśnica 2003).

Obok prawdy i mądrości do wartości fundamentalnych dla przygotowania młodego człowieka do życia - zarówno indywidualnego, jak i zbiorowego - należy zaliczyć sprawiedliwość i altruizm. Sprawiedliwość, rozumiana jako wola oddawania każdemu tego, co mu się należy zgodnie z jego uprawnieniem (Tomasz z Akwinu 1962-1986), na gruncie teologii tradycyjnie zaliczana jest - obok roztropności, męstwa i umiarkowania - do cnót kardynalnych, tzn. głównych, podstawowych, najważniejszych, takich, na których „zawieszone są” wszystkie inne cnoty (Jazukiewicz 2012) - do czego odsyła łacińska etymologia tego terminu: cardo znaczyło „zawias, czop, oś”.

Od czasów Sokratesa cnotę sprawiedliwości wiązano przede wszystkim z życiem społecznym i rozpatrywano w relacji do kategorii polis, choć równocześnie uznawano jako tę, która uwalnia duszę od „braku umiarkowania i bezprawia” oraz naprawia zniszczone relacje międzyludzkie (Świderek 2014).

I wreszcie altruizm - kategoria najmłodsza w zestawieniu obejmującym starożytnej proweniencji prawdę, mądrość i sprawiedliwość. Termin określający postawę kierowania się w swym postępowaniu dobrem innych (łacińskie alter znaczy „drugi”) i wiążący ją z bezinteresownością podmiotu został wprowadzony przez Augusta Comte’a, a rozpowszechniony przez pozytywistów (Encyklopedia $P W N)$. Choć stosunkowo młody i współcześnie bardzo spopularyzowany, altruizm doczekał się już redefinicji na gruncie takich dziedzin, jak: etologia, psychologia ewolucyjna i socjobiologia, generalnie nowe ujęcia altruizmu pozbawiają go aspektu bezinteresowności. Poszerza to zakres napięć w dyskursie wokół altruizmu poza spektrum stanowisk przeciwstawiających go miłości bliźniego, które to ujęcie forsował zwłaszcza Józef Bocheński (Bocheński 1987).

\section{Charakterystyka projektu badawczego}

Autor postanowił podjąć problem wpływu uposażenia aksjologicznego nauczycieli na kierunek rozwoju uczniów w wymiarze percepcji wartości. Uściślając przedmiotem prezentowanych tu badań jest związek pomiędzy rozumieniem prawdy, mądrości, sprawiedliwości i altruizmu przez nauczycieli a rozumieniem tych wartości przez ich podopiecznych - uczniów trzecich klas gimnazjum. Głównym zadaniem respondentów było określenie się na sześciopunktowej skali (parzysta liczba pomaga uniknąć zjawiska wybierania środka skali) w kwestii rozumienia tych wartości. Wymiary, na których badani dokonywali samookreślenia, uwzględniały dwa Kohlbergowskie komponenty rozumowania moralnego, a mianowicie perspektywę społeczną i treści moralne (Vasta i in. 2001; Trempała 1993). Po sprowadzeniu obu tych komponentów do wspólnego mianownika, jakim jest rozumowanie moralne, zostały wyznaczone krańce skal, które operacyjnie zostały zwerbalizowane przez frazy wyrażające odmienne sposoby rozumienia 
wymienionych powyżej wartości. Krańce te to opcja pragmatyczno-egocentryczna i opcja aksjologiczno-obiektywistyczna (Fankanowski 2014). W celu zminimalizowania ryzyka bezrefleksyjnego zaznaczania analogicznych odpowiedzi, określenia wyrażające każdą z opcji rozmieszczono w następujących po sobie pozycjach kwestionariuszowych naprzemiennie. Przedstawimy je teraz zgodnie z kolejnością występowania w kwestionariuszu: „Prawda to zgodność wypowiadanego zdania z rzeczywistością" (sformułowanie nawiązuje do klasycznej, korespondencyjnej definicji prawdy) vs. „Prawda to zgodność wypowiadanego zdania z moim odczuciem” (akcentowana jest subiektywność); „Mądrość to umiejętność podejmowania decyzji, które przynoszą korzyść” (zaznaczony jest pragmatyzm) vs. „Mądrość to zdolność do działania zwiększającego dobro ogólne”; „Sprawiedliwość polega na oddawaniu każdemu tego, co mu się należy" (nastawienie obiektywistyczno-allocentryczne) vs. „Sprawiedliwość to traktowanie innych tak, jak chciałoby się samemu być traktowanym” (nastawienie subiektywno-egocentryczne); „Altruizm to zachowanie dla mnie korzystne, gdyż inni czują się zwykle zobowiązani do wzajemności i udzielenia mi pomocy, gdy tego potrzebuję" vs. „Altruizm to dobrowolne ponoszenie pewnych kosztów na rzecz innych”. Określenie lewego krańca wymiaru altruizmu nawiązuje do tzw. „altruizmu odwzajemnionego” (Kozłowski 1996; Vasta i in. 2001) - rozumienia charakterystycznego dla podejścia ewolucyjnego do moralności, którym można uzasadniać zachowanie motywowane pragmatyczno-egocentrycznie. Zadaniem uczniów było także wyrażenie (na sześciopunktowej skali) swojego odczucia odnośnie wpływu, jaki na ich sposób rozumienia wartości wywarli nauczyciele. Po wypełnieniu pozycji kwestionariuszowych uczniowie proszeni byli o wypowiedź pisemną stymulowaną bodźcem narracyjnym: „Co uważasz na temat wpływu nauczyciela na rozumienie, uznawanie i realizowanie wartości przez ucznia - napisz parę słów na podstawie własnego doświadczenia”. Od nauczycieli oczekiwano podania w metryczkach ankiet swojego stażu pracy nauczycielskiej oraz stażu pracy w szkole, w której przeprowadzano badanie.

\section{Prezentacja wyników badania}

W badaniu wzięło udział 29 nauczycieli mających lekcje z trzecioklasistami w jednym $\mathrm{z}$ dużych wrocławskich gimnazjów publicznych oraz ich 142 uczniów z sześciu klas trzecich - młodzież w ogromnej większości rocznikowo szesnastoletnia, kończąca wkrótce szkołę gimnazjalną i mająca dwuipółletni kontakt z obecną szkołą i jej gronem pedagogicznym. Poniżej zaprezentowano dane uzyskane w badaniu.

W interpretacji danych przyjęto, że:

- odległość liczbowa (XO) średniej arytmetycznej (m) w danej grupie osób badanych od środka skali $(\mathbf{O}=3,5)$ większa niż odchylenie standardowe (s) dla tej grupy świadczy o bardzo silnym natężeniu tendencji w rozumieniu wartości, którą opisuje bliższy biegun skali, zaś XO mniejsza niż wartość s i większa niż 0,5 - świadczy o jej umiarkowanym natężeniu; 
- XO mniejsza lub równa 0,5 wskazuje na rozumienie pośrednie (nie wyraża ani opcji pragmatyczno-egocentrycznej, ani aksjologiczno-obiektywistycznej);

- odczytanie tendencji w oparciu o wartości XO i s jest modulowane w oparciu o medianę (Me) i dominantę (modalną - Mo), zwłaszcza odnośnie do średnich w przedziale: $\mathrm{O}-0,5 ; \mathrm{O}+0,5$ (czyli w przedziale: 3,0; 4,0);

- analogicznie - pod względem interpretacji miar statystycznych - przyjęto względem uśrednionego deklarowanego przez uczniów wpływu nauczycieli na sposób rozumienia wartości (jego wartość w przypadku każdej z grup znajdowała się pomiędzy punktem $\mathrm{O}$ a biegunem opisującym brak jakiegokolwiek wpływu): wartość XO większa niż s - silne przekonanie o braku wpływu; wartość XO między 0,5 a wartością $s$ - umiarkowane przekonanie o braku wpływu; XO w przedziale: $\mathrm{O} ; \mathrm{O}+0,50$ (czyli w przedziale: 3,$5 ; 4,0)$ - brak dominujących opinii (wynik pośredni).

Przy prezentacji danych zastosowano następujące skróty i oznaczenia:

n - liczba osób w danej grupie; K - kobiety; M - mężczyźni; b.d. - osoby badane, które nie podały swojej płci; śr. st. - średni staż pracy; śr. szk. - średni staż w tej szkole; r. aksj.-obiekt. - rozumienie aksjologiczno-obiektywistyczne; r. pragm.-egoc. - rozumienie pragmatyczno-egocentryczne; r. p. - rozumienie pośrednie.

W tabeli 1 zaprezentowano preferencje aksjologiczne badanych grup i deklarowany przez uczniów wpływ nauczycieli na ich sposób rozumienia wartości.

Tabela 1. Miary tendencji centralnej określające sposoby rozumienia wartości charakterystycznych dla poszczególnych grup nauczycieli i uczniów

\begin{tabular}{|l|c|c|c|c|c|l|}
\hline \multicolumn{1}{|c|}{ Wartość } & m & XO & s & Me & Mo & Operacjonalizacja wskaźników \\
\hline $\begin{array}{l}\text { Nauczyciele uczący klasy trzecie: } \mathrm{n}=29 ; 18 \text { K; } 6 \text { M; } 5 \text { b.d.; śr. st. = 13,78; śr. szk. } \\
=8,30\end{array}$ \\
\hline Prawda & 2,14 & 1,36 & 1,68 & 1 & 1 & dominacja r. aksj.-obiekt. \\
\hline Mądrość & 4,76 & 1,26 & 1,18 & 5 & 5 & $\begin{array}{l}\text { bardzo wyraźna dominacja } \\
\text { r. aksj.-obiekt. }\end{array}$ \\
\hline Sprawiedliwośćc & 4,24 & 0,74 & 1,88 & 5 & 6 & $\begin{array}{l}\text { umiarkowana dominacja } \\
\text { r. pragm.-egoc. }\end{array}$ \\
\hline Altruizm & 5,10 & 1,60 & 1,42 & 6 & 6 & $\begin{array}{l}\text { bardzo mocna dominacja } \\
\text { r. aksj.-obiekt. }\end{array}$ \\
\hline Uczniowie klas trzecich: n $=142 ; 81 \mathrm{~K} ; 61$ M \\
\hline Prawda & 2,50 & 1,00 & 1,39 & 2 & 1 & dominacja r. aksj.-obiekt. \\
\hline Mądrość & 3,35 & 0,15 & 1,57 & 3 & 3 & dominacja r. p. \\
\hline Sprawiedliwośćc & 3,98 & 0,48 & 1,70 & 4 & 6 & $\begin{array}{l}\text { dominacja r. p. z tendencją } \\
\text { do r. pragm.-egoc. }\end{array}$ \\
\hline
\end{tabular}




\begin{tabular}{|l|c|c|c|c|c|l|}
\hline \multicolumn{1}{|c|}{ Wartość } & m & XO & s & Me & Mo & Operacjonalizacja wskaźników \\
\hline Altruizm & 4,18 & 0,68 & 1,51 & 4 & 6 & $\begin{array}{l}\text { umiarkowana dominacja } \\
\text { r. aksj.-obiekt. }\end{array}$ \\
\hline Deklarowany wpływ nauczycieli na sposób rozumienia wartości \\
\hline \multicolumn{7}{|l|}{} \\
\hline $\begin{array}{l}\text { Nauczyciele uczący klasę 3a: } \mathrm{n}=10 ; 8 \\
\text { 9,40 }\end{array}$ \\
\hline Prawda & 2,40 & 1,10 & 2,27 & 1 & 1 & M; 1 b.d.; śr. st. = 12,o5; śr. szk. = \\
\hline Mądrość & 5,10 & 1,60 & 0,99 & 5 & $5 ; 6$ & $\begin{array}{l}\text { bardzo wyraźna dominacja } \\
\text { r. aksj.-obiekt }\end{array}$ \\
\hline Sprawiedliwośćc & 4,50 & 1,00 & 2,01 & 5,5 & 6 & dominacja r. pragm.-egoc. \\
\hline Altruizm & 4,70 & 1,20 & 1,70 & 5,5 & 6 & dominacja r. aksj.-obiekt. \\
\hline
\end{tabular}

Uczniowie 3a: $\mathrm{n}=22 ; 15 \mathrm{~K} ; 7 \mathrm{M}$

\begin{tabular}{|l|c|c|c|c|c|l|}
\hline Prawda & 2,91 & 0,59 & 1,77 & 3 & 1 & $\begin{array}{l}\text { W małym stopniu dominacja } \\
\text { r. aksj.-obiekt. }\end{array}$ \\
\hline Mądrość & 3,18 & 0,32 & 1,37 & 3,5 & 4 & dominacja r. p. \\
\hline Sprawiedliwość & 4,64 & 1,14 & 1,53 & 5 & 6 & dominacja r. pragm.-egoc. \\
\hline Altruizm & 3,43 & 0,07 & 1,36 & 3 & 3 & dominacja r. p. \\
\hline
\end{tabular}

\section{Deklarowany wpływ nauczycieli na sposób rozumienia wartości}

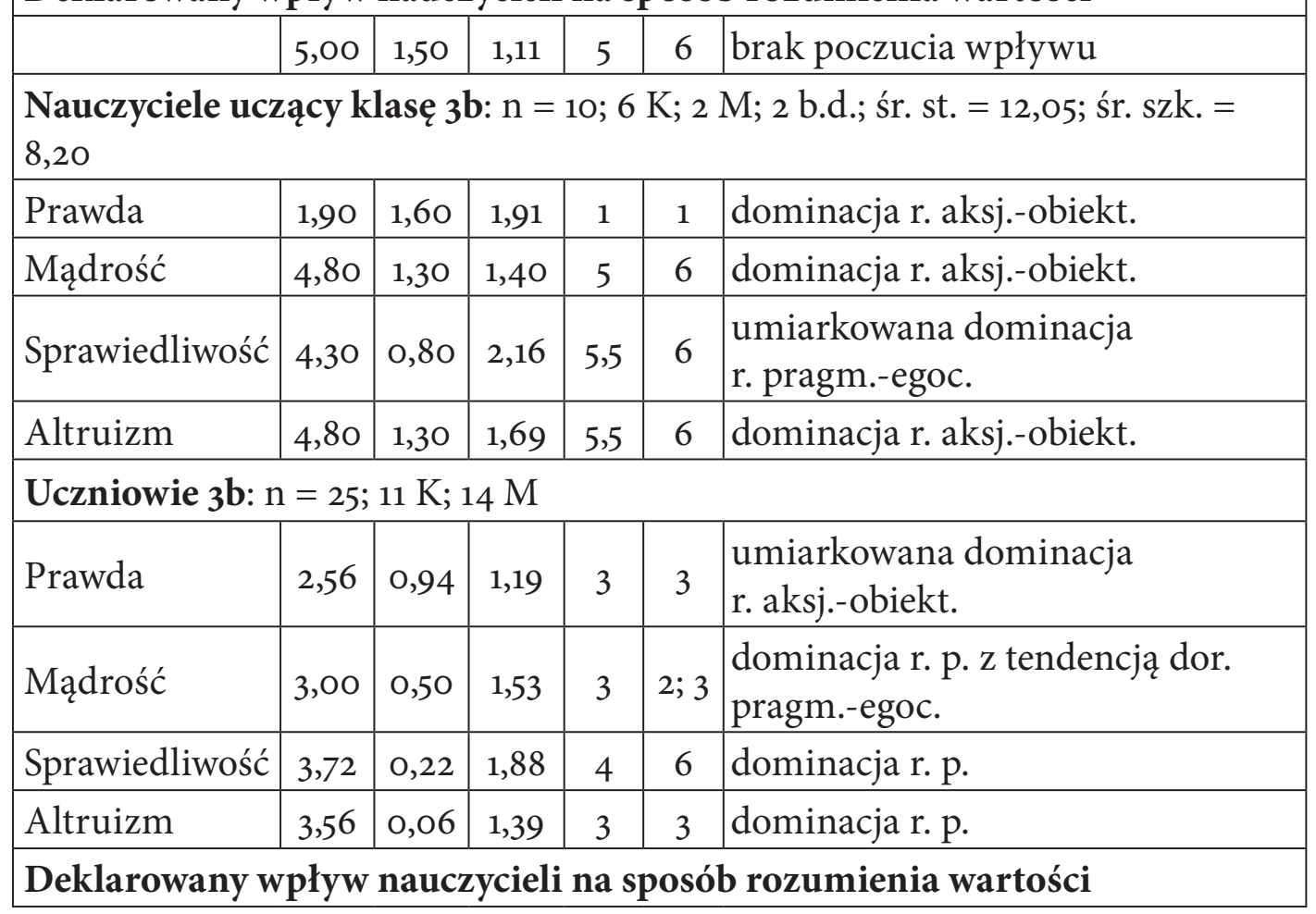




\begin{tabular}{|c|c|c|c|c|c|c|}
\hline Wartość & $\mathbf{m}$ & XO & $\mathbf{s}$ & Me & Mo & Operacjonalizacja wskaźników \\
\hline & 5,04 & 1,54 & 0,61 & 5 & 5 & brak poczucia wpływu \\
\hline \multicolumn{7}{|c|}{$\begin{array}{l}\text { Nauczyciele uczący klasę 3c: } n=15 ; 10 \mathrm{~K} ; 3 \mathrm{M} ; 2 \text { b.d.; śr. st. = 16,10; śr. szk. = } \\
9,97\end{array}$} \\
\hline Prawda & 2,60 & 0,90 & 1,99 & 2 & 1 & $\begin{array}{l}\text { umiarkowana dominacja } \\
\text { r. aksj.-obiekt. }\end{array}$ \\
\hline Mądrość & 4,73 & 1,23 & 1,16 & 5 & 5 & $\begin{array}{l}\text { bardzo wyraźna dominacja } \\
\text { r. aksj.-obiekt. }\end{array}$ \\
\hline Sprawiedliwość & 4,00 & 0,50 & 1,89 & 4 & $4 ; 6$ & $\begin{array}{l}\text { dominacja r. p. } z \text { tendencją } \\
\text { do r. pragm.-egoc. }\end{array}$ \\
\hline Altruizm & 4,73 & 1,23 & 1,75 & 6 & 6 & dominacja r. aksj.-obiekt. \\
\hline \multicolumn{7}{|c|}{ Uczniowie 3c: $n=22 ; 11 \mathrm{~K} ; 11 \mathrm{M}$} \\
\hline Prawda & 2,23 & 1,27 & 1,23 & 2 & 2 & $\begin{array}{l}\text { bardzo wyraźna dominacja } \\
\text { r. aksj.-obiekt. }\end{array}$ \\
\hline Mądrość & 3,68 & 0,18 & 1,55 & 4 & 4 & dominacja r. p. \\
\hline Sprawiedliwość & 4,64 & 1,14 & 1,76 & 5,5 & 6 & dominacja r. pragm.-egoc. \\
\hline Altruizm & 3,86 & 0,36 & 1,52 & 4 & 3 & dominacja r. p. \\
\hline \multicolumn{7}{|c|}{ Deklarowany wpływ nauczycieli na sposób rozumienia wartości } \\
\hline & 3,91 & 0,41 & 1,69 & 3 & 3 & $\begin{array}{l}\text { wynik pośredni; uwidacznia się } \\
\text { opinia o wpływie nauczycieli }\end{array}$ \\
\hline \multicolumn{7}{|c|}{ Nauczyciele uczący klasę 3d: $n=11 ; 4$ K; 4 M; 3 b.d.; śr. st. = 13,27; śr. szk. = 9,22 } \\
\hline Prawda & 1,91 & 1,59 & 1,81 & 1 & 1 & dominacja r. aksj.-obiekt. \\
\hline Mądrość & 4,36 & 0,86 & 1,29 & 5 & 5 & $\begin{array}{l}\text { umiarkowana dominacja } \\
\text { r. aksj.-obiekt. }\end{array}$ \\
\hline Sprawiedliwość & 3,82 & 0,32 & 1,99 & 4 & 6 & $\begin{array}{l}\text { dominacja r. p. } z \text { tendencją } \\
\text { do r. pragm.-egoc. }\end{array}$ \\
\hline Altruizm & 5,45 & 1,95 & 0,82 & 6 & 6 & $\begin{array}{l}\text { bardzo wyraźna dominacja r. aksj.- } \\
\text {-obiekt. }(\mathrm{XO} \approx \mathbf{2 , 4} \mathbf{s} !)\end{array}$ \\
\hline \multicolumn{7}{|c|}{ Uczniowie 3d: $n=28 ; 23 \mathrm{~K} ; 5 \mathrm{M}$} \\
\hline Prawda & 2,61 & 0,89 & 1,66 & 2 & 1 & $\begin{array}{l}\text { umiarkowana dominacja r. } \\
\text { aksj.-obiekt. }\end{array}$ \\
\hline Mądrość & 3,18 & 0,32 & 1,61 & 3 & 3 & dominacja r. p. \\
\hline Sprawiedliwość & 3,82 & 0,32 & 1,83 & 4 & $4 ; 6$ & dominacja r. p. \\
\hline Altruizm & 4,79 & 1,29 & 1,47 & 5 & 6 & dominacja r. aksj.-obiekt. \\
\hline \multicolumn{7}{|c|}{ Deklarowany wpływ nauczycieli na sposób rozumienia wartości } \\
\hline
\end{tabular}




\begin{tabular}{|c|c|c|c|c|c|c|}
\hline Wartość & m & XO & $\mathbf{s}$ & Me & Mo & Operacjonalizacja wskaźników \\
\hline & 4,96 & 1,46 & 1,14 & 5 & 6 & brak poczucia wpływu \\
\hline \multicolumn{7}{|c|}{ Nauczyciele uczący klasę 3e: $n=12 ; 9$ K; 1 M; 2 b.d.; śr. st. = 12,63; śr. szk. = 10,25 } \\
\hline Prawda & 2,00 & 1,50 & 1,35 & 1,5 & 1 & $\begin{array}{l}\text { bardzo wyraźna dominacja } \\
\text { r. aksj.-obiekt. }\end{array}$ \\
\hline Mądrość & 4,83 & 1,33 & 1,03 & 5 & 5 & $\begin{array}{l}\text { bardzo wyraźna dominacja } \\
\text { r. aksj.-obiekt. }\end{array}$ \\
\hline Sprawiedliwość & 4,08 & 0,58 & 2,11 & 4,5 & 6 & $\begin{array}{l}\text { w małym stopniu dominacja } \\
\text { r. pragm.-egoc. }\end{array}$ \\
\hline Altruizm & 5,17 & 1,67 & 1,03 & 5,5 & 6 & $\begin{array}{l}\text { bardzo wyraźna dominacja } \\
\text { r. aksj.-obiekt. }\end{array}$ \\
\hline \multicolumn{7}{|c|}{ Uczniowie 3e: $\mathrm{n}=26 ; 12 \mathrm{~K} ; 14 \mathrm{M}$} \\
\hline Prawda & 1,96 & 1,54 & 0,96 & 2 & 1 & $\begin{array}{l}\text { bardzo wyraźna dominacja } \\
\text { r. aksj.-obiekt. }\end{array}$ \\
\hline Mądrość & 3,88 & 0,38 & 1,75 & 4 & 6 & $\begin{array}{l}\text { dominacja r. p. } z \text { tendencją } \\
\text { do r. aksj.-obiekt. }\end{array}$ \\
\hline Sprawiedliwość & 3,67 & 0,17 & 1,54 & 3 & 3 & dominacja r.p. \\
\hline Altruizm & 4,77 & 1,27 & 1,48 & 5 & 6 & dominacja r. aksj.-obiekt. \\
\hline \multicolumn{7}{|c|}{ Deklarowany wpływ nauczycieli na sposób rozumienia wartości } \\
\hline & 5,31 & 1,81 & 0,84 & 5 & $5 ; 6$ & brak poczucia wpływu \\
\hline \multicolumn{7}{|c|}{ Nauczyciele uczący klasę 3f: $n=11 ; 8 \mathrm{~K} ; 2 \mathrm{M} ; 1$ b.d.; śr. st. = 13,41; śr. szk. = 9,36 } \\
\hline Prawda & 1,64 & 1,86 & 1,50 & 1 & 1 & $\begin{array}{l}\text { bardzo wyraźna dominacja } \\
\text { r. aksj.-obiekt. }\end{array}$ \\
\hline Mądrość & 5,27 & 1,77 & 0,90 & 5 & $5 ; 6$ & $\begin{array}{l}\text { bardzo wyraźna dominacja } \\
\text { r. aksj.-obiekt. }\end{array}$ \\
\hline Sprawiedliwość & 3,82 & 0,32 & 2,36 & 4 & 6 & $\begin{array}{l}\text { dominacja r. p. } z \text { tendencją do } \\
\text { r. pragm.-egoc. }\end{array}$ \\
\hline Altruizm & 4,91 & 1,41 & 1,70 & 6 & 6 & dominacja r. aksj.-obiekt. \\
\hline \multicolumn{7}{|c|}{ Uczniowie 3f: $\mathrm{n}=19 ; 9 \mathrm{~K} ; 10 \mathrm{M}$} \\
\hline Prawda & 2,82 & 0,68 & 1,26 & 3 & 3 & $\begin{array}{l}\text { umiarkowana dominacja } \\
\text { r. aksj.-obiekt. }\end{array}$ \\
\hline Mądrość & 3,11 & 0,39 & 1,45 & 3 & 2 & dominacja r.p. \\
\hline Sprawiedliwość & 3,45 & 0,05 & 1,32 & 4 & 4 & dominacja r.p. \\
\hline Altruizm & 4,47 & 0,97 & 1,31 & 5 & 5 & $\begin{array}{l}\text { umiarkowana dominacja } \\
\text { r. aksj.-obiekt. }\end{array}$ \\
\hline
\end{tabular}




\begin{tabular}{|c|c|c|c|c|c|l|}
\hline Wartość & m & XO & s & Me & Mo & Operacjonalizacja wskaźników \\
\hline & 4,5 & 1,00 & 1,04 & 4 & 4 & $\begin{array}{l}\text { umiarkowane poczucie braku } \\
\text { wpływu }\end{array}$ \\
\hline
\end{tabular}

Porównajmy odpowiednie średnie wartości liczbowe (m), opisujące preferencje aksjologiczne nauczycieli i ich uczniów. W poniższym zestawieniu za znaczącą przyjęto różnicę między średnimi większą niż wartość s dla danej dymensji przynajmniej dla jednej z porównywanych grup - świadczy ona o dużym przesunięciu rozumienia wartości przez uczniów w stosunku do rozumienia ich przez nauczycieli.

Różnica większa niż o,5 i mniejsza od niższej z wartości s świadczy o umiarkowanym przesunięciu jednej średniej względem drugiej. Zawarte w tabeli 2 zestawienie średnich arytmetycznych $(\mathrm{m})$ badanych grup uwyraźnia różnice w sposobie rozumienia wartości przez nauczycieli $(\mathrm{N})$ i uczniów $(\mathrm{U})$.

Tabela 2. Zestawienie średnich arytmetycznych wyrażających preferencje aksjologiczne nauczycieli i uczniów.

\begin{tabular}{|c|c|c|c|c|}
\hline Wartość & $\begin{array}{c}\text { m } \\
\text { grupa } \\
\mathbf{N}\end{array}$ & $\begin{array}{c}\text { m } \\
\text { grupa } \\
\mathbf{U}\end{array}$ & $\begin{array}{l}\text { Różnica } \\
\text { pomiędzy } \\
\text { średnimi }\end{array}$ & $\begin{array}{c}\text { Operacjonalizacja róż- } \\
\text { nicy - przesunięcie rozu- } \\
\text { mienia wartości w kierunku } \\
\text { pragmatyczno-egocentrycznym } \\
\text { u uczniów }\end{array}$ \\
\hline \multicolumn{5}{|c|}{ Nauczyciele uczący klasy 3 i uczniowie klas 3} \\
\hline Prawda & 2,14 & 2,50 & 0,36 & Ledwie zarysowane \\
\hline Mądrość & 4,76 & 3,35 & 1,41 & DUŻE \\
\hline Sprawiedliwość & 4,24 & 3,98 & 0,26 & Ledwie zarysowane \\
\hline Altruizm & 5,10 & 4,18 & 0,92 & Umiarkowane \\
\hline \multicolumn{5}{|l|}{ Klasa 3a } \\
\hline Prawda & 2,40 & 2,91 & 0,51 & Umiarkowane \\
\hline Mądrość & 5,10 & 3,18 & 1,92 & DUŻE \\
\hline Sprawiedliwość & 4,50 & 4,64 & 0,14 & Brak różnicy \\
\hline Altruizm & 4,70 & 3,43 & 1,27 & Umiarkowane \\
\hline \multicolumn{5}{|l|}{ Klasa 3b } \\
\hline Prawda & 1,90 & 2,56 & 0,66 & Umiarkowane \\
\hline Mądrość & 4,80 & 3,00 & 1,80 & DUŻE \\
\hline Sprawiedliwość & 4,30 & 3,72 & 0,58 & Umiarkowane \\
\hline Altruizm & 4,80 & 3,56 & 1,24 & Umiarkowane \\
\hline \multicolumn{5}{|l|}{ Klasa 3c } \\
\hline Prawda & 2,60 & 2,23 & 0,37 & Ledwie zarysowane \\
\hline
\end{tabular}




\begin{tabular}{|c|c|c|c|c|}
\hline Wartość & $\begin{array}{c}\text { m } \\
\text { grupa } \\
\mathbf{N}\end{array}$ & $\begin{array}{c}\text { m } \\
\text { grupa } \\
\mathbf{U}\end{array}$ & $\begin{array}{l}\text { Różnica } \\
\text { pomiędzy } \\
\text { średnimi }\end{array}$ & $\begin{array}{c}\text { Operacjonalizacja róż- } \\
\text { nicy - przesunięcie rozu- } \\
\text { mienia wartości w kierunku } \\
\text { pragmatyczno-egocentrycznym } \\
\text { u uczniów }\end{array}$ \\
\hline Mądrość & 4,73 & 3,68 & 1,05 & Umiarkowane \\
\hline Sprawiedliwość & 4,00 & 4,64 & 0,64 & Umiarkowane \\
\hline Altruizm & 4,73 & 3,86 & 0,87 & Umiarkowane \\
\hline \multicolumn{5}{|l|}{ Klasa 3d } \\
\hline Prawda & 1,91 & 2,61 & 0,70 & Umiarkowane \\
\hline Mądrość & 4,36 & 3,18 & 1,18 & Umiarkowane \\
\hline Sprawiedliwość & 3,82 & 3,82 & $\mathrm{O}$ & Brak różnicy \\
\hline Altruizm & 5,45 & 4,79 & 0,66 & Umiarkowane \\
\hline \multicolumn{5}{|l|}{ Klasa 3e } \\
\hline Prawda & 2,00 & 1,96 & 0,04 & Brak różnicy \\
\hline Mądrość & 4,83 & 3,88 & 0,95 & Umiarkowane \\
\hline Sprawiedliwość & 4,08 & 3,67 & 0,41 & Ledwie zarysowane \\
\hline Altruizm & 5,17 & 4,77 & 0,40 & Ledwie zarysowane \\
\hline \multicolumn{5}{|l|}{ Klasa $3 f$} \\
\hline Prawda & 1,64 & 2,82 & 1,18 & Umiarkowane \\
\hline Mądrość & 5,27 & 3,11 & 2,16 & DUŻE \\
\hline Sprawiedliwość & 3,82 & 3,45 & 0,37 & Ledwie zarysowane \\
\hline Altruizm & 4,91 & 4,47 & 0,44 & Ledwie zarysowane \\
\hline
\end{tabular}

\section{Co wynika z uzyskanych danych?}

Najogólniejszy wniosek nie napawa optymizmem: u uczniów występuje na ogół istotne przesunięcie rozumienia wartości w kierunku pragmatyczno-egocentrycznym w stosunku do rozumienia ich przez nauczycieli.

Interesująco przedstawia się zróżnicowanie tego przesunięcia względem poszczególnych wartości. Zarówno w grupie wszystkich trzecioklasistów, jak i w poszczególnych klasach z największym przesunięciem sposobu rozumienia w kierunku pragmatyczno-egocentrycznym mamy do czynienia odnośnie do mądrości. W liczbach bezwzględnych wygląda to następująco (w nawiasach: wartości s w grupach $\mathrm{N} \mathrm{i} \mathrm{U):}$

- ogół trzecioklasistów - 1,41 (N - 1,18; U - 1,57);

- kl. $3 \mathrm{a}-\mathbf{1 , 9 2}(\mathrm{N}-0,99 ; \mathrm{U}-1,37)$;

- kl. $3 \mathrm{~b}-\mathbf{1 , 8 0}(\mathrm{N}-1,40$; $\mathrm{U}-1,53)$;

$-\mathrm{kl} .3 \mathrm{C}-1, \mathrm{O} 5(\mathrm{~N}-1,16$; U - 1,55); 
- kl. 3d - 1,18 (N-1,29; U - 1,61);

-kl. 3e-0,95 (N-1,03; U - 1,75);

- kl. $3 f-2,16$ ( N - o,90; U - 1,45).

W przypadku ogółu trzecioklasistów oraz klas 3a, 3b i 3 f nie tylko różnica pomiędzy średnimi jest większa od wartości s dla co najmniej jednej z grup, ale średnia dla uczniów znajduje się po drugiej stronie środka skali w odróżnieniu od średniej dla ich nauczycieli - co świadczy o różnicy jakościowej (dla 3d średnie też są po dwóch stronach środka skali, ale różnica jest mniejsza od wartości s). Jak widać w większości grup uczniowskich przesunięcie w kierunku pragmatyczno-egocentrycznym rozumienia mądrości jest większe niż wartość s dla którejkolwiek z porównywanych grup.

Z kolei najmniejsza różnica między podejściem do wartości nauczycieli i uczniów występuje odnośnie do sprawiedliwości. W przypadku ogółu uczniów klas 3 różnica jest ledwie zarysowana - 0,26 (N - 1,88; U - 1,70). Jeszcze wyraźniej prawidłowość ta ujawnia się w klasach: $3 a-0,14(\mathrm{~N}-2,01 ; \mathrm{U}-1,53)$ i 3d - dokładnie o $(\mathrm{N}-1,99 ; \mathrm{U}-1,83)$ - brak tam różnicy między podejściem uczniów i nauczycieli. W klasach 3e i 3 f różnica jest ledwie zarysowana (3e - 0,41; $\mathrm{N}-2,11 ; \mathrm{U}-1,54$; $3 \mathrm{f}-0,37 ; \mathrm{N}-2,36 ; \mathrm{U}-1,32)$, a tylko w klasach $3 \mathrm{~b}$ i $3 \mathrm{c}$ jest umiarkowana $(3 \mathrm{~b}-0,58$; $\mathrm{N}-2,16 ; \mathrm{U}-1,88 ; 3 \mathrm{C}-0,64 ; \mathrm{N}-1,89 ; \mathrm{U}-1,76$ ).

Małe różnice między nauczycielami i uczniami wystąpiły w kwestii rozumienia prawdy - w przypadku ogółu trzecioklasistów średnie przesunięcie opinii uczniowskich względem nauczycielskich jest ledwie zarysowane i wynosi o,36 (N - 1,68; $\mathrm{U}-1,39)$. W klasie ze przesunięcie nie zachodzi (o,04; $\mathrm{N}-1,35 ; \mathrm{U}-0,96)$, zaś w $3 \mathrm{C}$ jest ledwie zarysowane $(0,37 ; \mathrm{N}-1,99 ; \mathrm{U}-1,23)$. W klasach 3a, 3b, 3d i 3 f przesunięcie jest umiarkowane $(3 \mathrm{a}-0,51 ; \mathrm{N}-2,27 ; \mathrm{U} 1,77 ; 3 \mathrm{~b}-0,66 ; \mathrm{N}-1,91 ; \mathrm{U}-1,19 ; 3 \mathrm{~d}-0,70$; $\mathrm{N}-1,81 ; \mathrm{U}-1,66 ; 3 \mathrm{f}-1,18 ; \mathrm{N}-1,50 ; \mathrm{U}-1,26)$.

Jeśli chodzi o rozumienie altruizmu, to dominuje umiarkowane przesunięcie w kierunku pragmatyczno-egocentrycznym. Jest tak w przypadku ogółu trzecioklasistów (0,92; N - 1,42; U - 1,51) oraz w klasach 3a (1,27; N - 1,70; U - 1,36), 3b (1,24; N - 1,69; U - 1,39), 3c (0,87; N - 1,75; U - 1,52) i 3d (0,66; N - o,82; U - 1,47). Natomiast w klasach 3 e i 3 f przesunięcie ledwie się zarysowuje (3e - 0,40; N - 1,03; $\mathrm{U}-1,48 ; 3 \mathrm{f}-0,44 ; \mathrm{N}-1,70 ; \mathrm{U}-1,31$ ).

Być może warto porównać wielkość przesunięcia rozumienia przez uczniów wartości w kierunku pragmatyczno-egocentrycznym w poszczególnych grupach uczniów z deklarowanym przez nich wpływem aksjologicznym nauczycieli. W większości grup uczniowskich bardzo silnie dominuje przekonanie o braku wpływu. Jest tak w grupie wszystkich uczniów oraz w klasach: 3a, 3b, 3d i 3e. Na tym tle wyróżniają się klasy: $3 \mathrm{f}$ - gdzie panuje umiarkowane przekonanie o braku wpływu $(\mathrm{m}=4,5 ; \mathrm{XO}=1 ; \mathrm{s}=1,04)$ oraz przede wszystkim klasa $3 \mathrm{c}$ - gdzie średnia m $(3,91)$ jest koło środka skali, wielkość XO $(0,41)$ jest parokrotnie mniejsza od wartości s (1,69), a wartości Me i Mo są poniżej środka skali (obie wynoszą 3), co 
w kontekście wyników w innych grupach uczniowskich można rozumieć jako uwidocznienie się opinii o istotnym wpływie nauczycieli.

Idąc tropem przekonań odróżniających się od ogółu odnośnie do aksjologicznego wpływu nauczycieli, warto przyjrzeć się nieco bliżej specyfice nauczycieli uczących w wyróżniających się pod tym względem klasach. Przyjmując za odniesienie wartości średnich arytmetycznych preferencji aksjologicznych w najszerszej grupie badanych nauczycieli, zauważamy, że uczący klasę $3 \mathrm{f}$ w dwóch wymiarach - tzn. w kwestiach rozumienia prawdy oraz mądrości - wyróżniają się spośród badanych gremiów bardzo wyraźną dominacją rozumienia aksjologiczno-obiektywistycznego. Natomiast grono uczących 3c wyróżnia się wśród badanych nauczycieli tylko najdłuższym ogólnym stażem pracy, nie wykazując szczególnych różnic w preferencjach aksjologicznych.

Z kolei wychodząc od wyróżniających się dominującą orientacją aksjologiczną grup nauczycieli, trzeba zwrócić uwagę na grona uczące klasy $3 \mathrm{e}$ i $3 \mathrm{f}$. W gronie pedagogicznym uczącym ze w trzech z czterech dymensji bardzo wyraźnie dominuje rozumienie aksjologiczno-obiektywistyczne - dotyczy to prawdy, mądrości i altruizmu - i ma ono większe natężenie niż w całej grupie badanych nauczycieli. Uczniowie tego grona wykazują:

- w kwestii rozumienia prawdy - bardzo wyraźną dominację opcji aksjologiczno-obiektywistycznej;

- w kwestii rozumienia mądrości - podejście pośrednie z tendencją do aksjologiczno-obiektywistycznego;

- w przypadku sprawiedliwości - rozumienie pośrednie i

- względem altruizmu - umiarkowaną dominację rozumienia aksjologiczno-obiektywistycznego.

Ta grupa uczniów przejawia większe natężenie rozumienia aksjologiczno-obiektywistycznego od ogółu trzecioklasistów w tych samych wymiarach, co uczący ich nauczyciele względem swojej grupy odniesienia, a w dwóch wymiarach (prawda i mądrość) uczniowie 3e mają najwyższe spośród badanych grup uczniowskich wskaźniki opcji obiektywistycznej. Równocześnie nie widzą oni wpływu nauczycieli na ich sposób rozumienia wartości.

Grono uczące $3 \mathrm{f}$ zostało powyżej scharakteryzowane. Natomiast preferencje aksjologiczne tej klasy wyglądają następująco: w małym stopniu dominuje obiektywistyczne rozumienie prawdy, ujawnia się pośrednie rozumienie mądrości z tendencją do pragmatyczno-egocentrycznego, dominuje pośrednie rozumienie sprawiedliwości i umiarkowanie obiektywistyczne rozumienie altruizmu.

Spośród wartości miar statystycznych zwraca jeszcze uwagę bardzo wysoki stopień dominacji obiektywistycznego rozumienia altruizmu w gronie uczących 3d (najwyższy wśród wszystkich grup występujących w badaniach). U uczniów tej klasy również dominuje obiektywistyczne rozumienie tej wartości (najwyższy wskaźnik wśród grup uczniowskich). A więc zarówno uczący w 3d, jak i jej uczniowie znacząco wyróżniają się w tym samym wymiarze aksjologicznym. 


\section{Przykłady wypowiedzi uczniowskich}

Ilustracją tendencji dominujących w postawach uczniów i ujawniających się w badaniach ilościowych oraz w wypowiedziach otwartych stymulowanych prośbą, „, co uważasz na temat wpływu nauczyciela na rozumienie, uznawanie i realizowanie wartości przez ucznia - napisz parę słów na podstawie własnego doświadczenia", niech będą cytaty reprezentatywne dla większości wypowiedzi:

„Jeśli rodzice nie nauczyli dziecka tego, to może nauczyciele będą mogli go czegoś nauczyć" (K, kl. 3f);

„[Nauczyciele] mogą mieć wpływ, ale w moim wypadku raczej nie mieli. Rozumienie tych wartości jest możliwe dzięki moim przeżyciom i innym ludziom, ale nauczyciele nie wpłynęli jakoś szczególnie na mój światopogląd” (K, kl. 3f);

„Jeżeli ktoś ma dobry kontakt $\mathrm{z}$ nauczycielem, to ten może mieć jakiś wpływ na ucznia" (M, kl. 3f);

„Nauczyciele mogą wytłumaczyć nam, co jest dobre, a co nie, ale zwykle nie mają wpływu na to, czy uczeń zastosuje się do tego" (K, kl. 3f);

„Na moje postrzeganie świata wpływają rodzice, a nie nauczyciele” ( $\mathrm{M}, \mathrm{kl} .3 \mathrm{~d}$ ); „Nauczyciele swoim przykładem mogą pomagać w wytrwaniu przy swoich wartościach lub skłonić do refleksji nad słusznością wyznawanych wartości” (K, kl. 3e);

„Nauczyciel powinien być przykładem systemu wartości, a nie mówić o tym, jacy powinniśmy być, a potem robić odwrotnie, a tak często jest" (M, kl. 3e); „Nauczyciele mieli wpływ na mój sposób rozumienia wartości, ale nie mogę powiedzieć, że duży. W większości swój tok rozumowania opieram na codziennych doświadczeniach" (K, kl. 3f);

„Jeżeli ktoś ma dobry kontakt $\mathrm{z}$ nauczycielem, to ten może mieć jakiś wpływ na ucznia" (M, kl. 3f);

„Jest dosyć mały - na moje wartości ma wpływ garstka nauczycieli - szkoda, że tylko tylu" (M, kl.3d).

\section{Podsumowanie: odniesienia i wnioski}

Odnosząc uzyskane wyniki do literatury przedmiotu, należy wspomnieć, że w przeprowadzonych przez Ryszarda Jedlińskiego u końca lat 90. badaniach preferencji aksjologicznych piętnastolatków, spośród eksplorowanych w przedstawionych tu badaniach wartości, wśród pierwszych 10, którym respondenci przypisują największą ważność, znalazła się tylko sprawiedliwość (Karwatowska 2012). Jednak badania Jedlińskiego dotyczyły językowego obrazu świata wartości w wypowiedziach uczniów kończących ośmioletnią szkołę podstawową i nie identyfikowano sposobu rozumienia przez uczniów wartości, tylko nominalne deklaracje o ich ważności. Za 
Małgorzatą Karwatowską należy także przywołać semantyczny obraz nauczyciela, jaki ma młodzież gimnazjalna, ujawniony w badaniach prowadzonych przez tę autorkę. Najbliżej z rezultatami badań prezentowanych w niniejszym opracowaniu koresponduje odwzorowanie przez autorkę spojrzenia gimnazjalistów na zabiegi wychowawcze nauczycieli. Z zestawienia wypowiedzi uczniowskich Karwatowska rekonstruuje obraz ambiwalentny: „nauczyciel wpływa pozytywnie na kształtowanie osobowości wychowanka, ale bywa również osobą o niewielkich, a [...] nawet żadnych umiejętnościach wychowawczych, która nie przywiązuje jakiejkolwiek wagi do profilowania charakteru powierzonych mu młodych istot" (Karwatowska 2012, s. 154-155).

Ujawnione w zaprezentowanych badaniach trzecioklasistów gimnazjalnych przesunięcie rozumienia wartości przez uczniów w kierunku pragmatyczno-egocentrycznym w stosunku do rozumienia ich przez nauczycieli oraz silna dominacja przekonania o braku wpływu nauczycieli (w pięciu na sześć klas trzecich) zobowiązują do poważnego traktowania wyrażanej przez większość uczniów opinii mówiącej o małym wpływie nauczycieli na sposób rozumienia wartości. Równocześnie jednak ujawniła się delikatnie prawidłowość, iż postawy aksjologiczne nauczycieli pociągają w pewnym stopniu uczniów oraz co ciekawe uwyraźniła się bardziej tendencja głosząca, że oddziałują one na odczuwany przez uczniów wpływ aksjologiczny nauczycieli. W tej ostatniej materii nie bez znaczenia jest ogólny staż pracy nauczycielskiej - o czym dobitnie przekonują dane dotyczące klasy 3c.

Patrząc krytycznie na zaprezentowane badania, nie można uciec od refleksji o niewątpliwym wpływie na uzyskane dane użytych w kwestionariuszu sformułowań, będących przedmiotem ustosunkowania się respondentów. Związana z tym jest także popularność przypisywanych pewnym wartościom znaczeń w dyskursie publicznym - w tym konotacji popkulturowych - oddziałującym zarówno na nauczycieli, jak i uczniów. Temu prawdopodobnie należy przypisać fakt, iż rozumienie aksjologiczno-obiektywistyczne w obu grupach najwyraźniej ujawniło się względem altruizmu.

\section{Bibliografia}

Altruizm. W: Encyklopedia PWN. Dostępny na: http://encyklopedia.pwn.pl/haslo/ altruizm;3868318.html (otwarto 18.11.2015).

Bocheński J.M. (1987). Sto zabobonów. Krótki filozoficzny słownik zabobonów. Paryż: Instytut Literacki.

Dereń E. (brw). Rola nauczyciela w procesie kształcenia $i$ wychowania dzieci. Dostępny na: https://sites.google.com/site/ksztalcenienauczycieli/nauczyciel---zawod-czy-misja-i-powolanie/rola-nauczyciela-w-procesie-ksztalcenia-i-wychowania-dzieci (otwarto 19.01.2015). 
Fankanowski M. (2014). Sprawiedliwość w porządku cnót przyszłych nauczycieli. W: I. Jazukiewicz, E. Rojewska(red.). Nadzieja i sprawiedliwość jako sprawności moralne wychowaniu. Szczecin: Wydawnictwo Naukowe US.

Jazukiewicz I. (2012). Pedeutologiczna teoria cnoty. Szczecin: Wydawnictwo Naukowe US.

Karwatowska M. (2012). Autorytety w opiniach młodzieży. Lublin: Wydawnictwo UMCS.

Kozłowski J. (1996). Ewolucja zachowań altruistycznych. „Universitas”, nr 17 (2), s. 4-8. Dostępny na: http://www.eko.uj.edu.pl/ kozlo/pliki/Universitas_ewolucja\%20zachowa\%C5\%84\%20altruistycznych.pdf (otwarto 26.03.2013).

Kwaśnica R. (2003). Wprowadzenie do myślenia o nauczycielu. W: Z. Kwieciński, B. Śliwerski (red.). Pedagogika. Podręcznik akademicki, t. 2. Warszawa: PWN.

Szewczyk K. (1998). Wychować człowieka mąrego. Zarys etyki nauczycielskiej. Warszawa: PWN.

Świderek J. (2014). Sprawiedliwość jako forma Sokratejskiej cnoty. Aktualność implikacji pedagogicznych. W: I. Jazukiewicz, E. Rojewska(red.). Nadzieja i sprawiedliwość jako sprawności moralne wychowaniu. Szczecin: Wydawnictwo Naukowe US.

Tomasz z Akwinu, św. (1962-1986). Suma teologiczna. Tom 18. Sprawiedliwość. Londyn: Veritas.

Trempała J. (1993). Rozumowanie moralne i odporność dzieci na pokusę oszustwa, Bydgoszcz: Wydawnictwo Uczelniane WSP w Bydgoszczy.

Ustawa $z$ dnia 7 września 1991 r. o systemie oświaty. Dostępny na: http://isap.sejm. gov.pl/DetailsServlet?id=WDU19910950425 (otwarto 2.11.2015).

Vasta R., Haith M.H., Miller A. (2001). Psychologia dziecka. Rozwój moralny. Warszawa: WSiP.

Wołoszyn-Spirka W. (2014). Sprawiedliwość. W: I. Jazukiewicz, E. Rojewska(red.). Nadzieja i sprawiedliwość jako sprawności moralne wychowaniu. Szczecin: Wydawnictwo Naukowe US.

Woroniecki J. (1961). Długomyślność jako cnota wychowawcy. W: J. Woroniecki. Wychowanie człowieka. Pisma wybrane. Kraków: Znak.

\title{
THE TEACHERS' AXIOLOGICAL PREFERENCES AND PERCEPTION OF THE VALUES BY PUPILS
}

\begin{abstract}
The author conducted research concerning the link between understanding values by teachers and their pupils. 142 pupils of the third class of the junior secondary school (gimnazjum) and 29 of their teachers were examined. The task for respondents was to determine how they understand: truth, wisdom, justice and altruism on a scale which went from pragmatic-egocentric option to axiological-objectivist option. Additionally, pupils expressed how they perceive their teachers' influence on the way they understand
\end{abstract}


values. The research reveals pupils' significant tendency to understand values in a more pragmatic-egocentric way than their teachers do. According to young people's opinion teachers have very little influence on the way they understand values, nonetheless the relations the author discovered indicate that the influence is more significant.

Keywords: values, upbringing, truth, wisdom, justice, altruism.

Marcin Fankanowski - magister psychologii, zatrudniony na stanowisku starszego wykładowcy w Centrum Edukacji Nauczycielskiej Uniwersytetu Wrocławskiego. Zainteresowania badawcze: psychologia narracyjna, psychologia religii, psychologia i pedagogika wartości, etyka nauczycielska. Adres mejlowy: marcin.fankanowski@cen.uni.wroc.pl; marcin.fankanowski@uwr.edu.pl. 